\title{
Data on pubertal development in Greek boys. A longitudinal study
}

\author{
Kyratsoula Pantsiotou
}

National Health Service, Endocrine Clinic Athens, Greece

\begin{abstract}
OBJECTIVE: Longitudinal data on boys' puberty evolution are not available in Greece and very few such studies have been reported world-wide. We present data from a longitudinal study on height, weight, BMI and age at the different pubertal stages in Greek boys. DESIGN: At the start of the study 204 prepubertal boys aged 8-10 years, were enrolled. Measurements were carried out every 3-6 months for 7.5 years. RESULTS: At pubertal stage G2 the mean age and SD was $10.3(1.0)$, the height $143.4 \mathrm{~cm}$ or $82.3 \%$ of final height and the BMI $18.6 \mathrm{~kg} / \mathrm{m}^{2}$. Mean age at peak height velocity was 13.2 (1.0) years and at final height $17.1(0.9)$ years. At peak height velocity, the height accounted for $91.5 \%$ of the final height. The time elapsed from the beginning to the end of puberty (duration of pubertal process) was $6.2(0.6)$ years. The height gain during puberty was $31.0(4.0) \mathrm{cm}$ and the weight gain $36.3(8.1) \mathrm{kg}$. CONCLUSIONS: Longitudinal data on pubertal development are rather sparse, especially for males. Although the present study was carried out in an urban population of the Athens region, the data could be useful in delineating prognosis of puberty evolution and final height in boys.
\end{abstract}

Key words: Duration of Puberty, Height Growth during Puberty, Longitudinal data on boys' puberty, Peak Height Velocity.

\section{INTRODUCTION}

Puberty is a very important developmental stage of human growth. The timing of appearance of the secondary sex characteristics is dependent on both genetic and environmental factors. ${ }^{1}$ The improvement in socioeconomic conditions that took place in the last century resulted in earlier pubertal maturation

Address for correspondence:

MD PhD, Pantsiotou Kyratsoula, 11 Drosi Str, 11474 Gyzi,

Athens, Greece, Tel.: +30 210 6462190,

e-mail: pantsiot71@hotmail.com

Received 16-12-06, Revised 21-02-07, Accepted 10-03-07 of children, at least in the industrialized countries. ${ }^{2,3}$ The studies on the pubertal maturation of boys are much fewer than those of girls, mainly due to the difficulty in examining male genitalia, especially when puberty is advanced.

Most studies on pubertal maturation are crosssectional. ${ }^{4,5}$ Very few longitudinal studies have been reported, because such studies require a long period of time and present difficulties in maintaining the initial sample size. On the other hand, such data provide more precise information on the tempo of puberty, the time interval between the various pubertal stages 
and other processes like PHV.

\section{SUBJECTS AND METHODS}

In the present study data on pubertal development of Greek boys living in the Athens region are reported. Two hundred and four schoolboys aged 8-10 years old were initially enrolled. All the boys were of Greek origin and were recruited from schools of Athens districts inhabited mostly by people of the middle-toupper class. These schools were selected because they agreed to co-operate. Permission from the Ministry of Education and written consent of the children's guardian were obtained. At initiation of the study all boys were prepubertal (i.e. testicular volume $<3 \mathrm{ml}$ ). Measurements were carried out every 3-6 months for 7.5 years. At each examination, standing height was measured by portable Harpenden stadiometer according to established techniques. ${ }^{6}$ Body weight was measured with a Soehnle electronic weighing device. The testicular volume was measured using the Prader orchidometer. Pubertal staging [genitalia $(\mathrm{G})$, and pubic hair growth $(\mathrm{P})]$ were assessed using Tanner's criteria.

The mean age (SD) at the various pubertal stages as well as the mean value (SD) of standing height and the $50^{\text {th }}$ percentile value $\left(10^{\text {th }}-90^{\text {th }}\right)$ of weight at the various stages of puberty were estimated. We did not have an adequate number (10 boys) for stage 5 , because most boys refused to be examined. We also estimated the height velocity (HV) as well as the peak height velocity (PHV) in every boy and the \% of final height achieved at the various pubertal stages and at PHV. The Body Mass Index (BMI) value was derived using the formula weight $(\mathrm{Kg}) / \mathrm{height}\left(\mathrm{m}^{2}\right)$. Furthermore, we estimated the duration from onset of puberty to final height (i.e. $\mathrm{HV}<1 \mathrm{~cm} / \mathrm{yr}$ ). The height was recorded as final (n:40) when the height velocity the previous year was $<1 \mathrm{~cm}$.

Statistical analysis was carried out using SPSS/PC + 4.0 International BV, Netherlands.

\section{RESULTS}

The mean age $( \pm \mathrm{SD})$ at the various pubertal stages, at PHV and at peak weight velocity are shown in Table 1. The interval from G2 to G4 was $2.4(0.7)$
Table 1. Mean chronological age $( \pm S D)$ at prepuberty $(\mathrm{PP})$, at the different stages of pubertal development $(\mathrm{G})$ of pubic hair development (P), at peak height velocity (PHV), at peak weight velocity (PWV), and the various testes size.

\begin{tabular}{lcc}
\hline Pubertal status & Mean age $(\mathbf{S D})$, years & Testes size $(\mathbf{m l})$ \\
\hline PP & $9.3(0.8)$ & 3.0 \\
G2 & $10.3(1.0)$ & $4.3(1.0)$ \\
G3 & $11.9(1.0)$ & $10.3(1.0)$ \\
G4 & $12.9(0.8)$ & $14.2(2.0)$ \\
PHV & $13.2(1.0)$ & $15.0(3.0)$ \\
PWV & $13.5(1.1)$ & \\
P2 & $10.8(1.1)$ & \\
P3 & $12.4(0.9)$ & \\
P4 & $13.0(0.9)$ & \\
\hline
\end{tabular}

years. Pubic hair stage 2 (P2) developed 0.5 year after $\mathrm{G} 2$, at 10.8 (1.1) years. The interval from $\mathrm{P} 2$ to $\mathrm{P} 4$ was $2.2(0.9)$ years.

The height, weight and BMI values at the various stages of growth and development are shown in Table 2. The PHV was $11.0(2.2) \mathrm{cm} /$ year and was observed at a mean age of $13.2(1.0)$ years. The peak weight velocity was $15.5(4.8) \mathrm{kg} /$ year and was observed at a mean age of 13.5 (1.2) years. The mean final height was $175.9(5.1) \mathrm{cm}$ and was achieved at a mean age of $17.1(0.9)$ years.

One year before entering puberty (prepuberty-PP-) mean $\mathrm{HV}$ was $5.5 \mathrm{~cm} /$ year and the standing height accounted for $78.3 \%$ of the final height. At pubertal stage G2, there was no change in $\mathrm{HV}$, which was 5.6 $\mathrm{cm} /$ year. At PHV the standing height accounted for $91.5 \%$ of the final height.

At pubertal stage 2, median body weight was $37.9 \mathrm{~kg}$, comprising $55.4 \%$ of final body weight, and BMI was $18.6 \mathrm{~kg} / \mathrm{m}^{2}$. At PHV body weight was 54.5 $\mathrm{kg}$ and BMI was $20.4 \mathrm{~kg} / \mathrm{m}^{2}$. At the end of growth, median body weight was $74.8 \mathrm{~kg}$ and BMI was 24.3 $\mathrm{kg} / \mathrm{m}^{2}$. The total weight gain from pubertal stage $\mathrm{G} 2$ to final height was $36.3(8.1) \mathrm{kg}$.

Mean time interval of progression from G2 to PHV was 2.4 (1.0) years and to final height $6.2(0.6)$ years. Mean standing height gained from $\mathrm{G} 2$ to PHV was $16.6(2.4) \mathrm{cm}$ and to final height $31.0(4.0) \mathrm{cm}$. Mean time interval from PHV to final height was 
Table 2. Various parameters (mean $\pm \mathrm{SD}$ or centiles) at the different developmental stages

\begin{tabular}{|c|c|c|c|c|c|c|c|}
\hline & \multirow[b]{2}{*}{$\mathbf{N}$} & \multirow[b]{2}{*}{$\begin{array}{c}\text { Age (yrs) } \\
\text { mean (SD) }\end{array}$} & \multicolumn{2}{|c|}{ Height } & \multirow[b]{2}{*}{$\begin{array}{c}\text { Height velocity, } \\
\text { mean (SD), cm/year }\end{array}$} & \multirow[b]{2}{*}{$\begin{array}{c}\text { Body weight, } \mathrm{kg} \\
\mathbf{5 0}^{\text {th }}(\mathbf{1 0 - 9 0 )} \text { centiles }\end{array}$} & \multirow{2}{*}{$\begin{array}{c}\text { BMI, } \mathrm{kg} / \mathrm{m}^{2} \\
50^{\text {th }}(10-90) \\
\text { centiles }\end{array}$} \\
\hline & & & $\begin{array}{c}\text { cm } \\
\text { mean }(\mathrm{SD})\end{array}$ & $\begin{array}{c}\% \text { of final } \\
\text { height (SD) }\end{array}$ & & & \\
\hline PP & 129 & $9.3(0.8)$ & $137.8(6.4)$ & $78.3(1.4)$ & $5.5(1.5)$ & $33.3(28.1-43.5)$ & $17.5(15.4-21.6)$ \\
\hline $\mathrm{G} 2$ & 204 & $10.3(1.0)$ & $143.4(6.7)$ & $82.3(2.4)$ & $5.6(1.9)$ & $37.9(30.6-49.0)$ & $18.6(16.0-22.9)$ \\
\hline G3 & 98 & $11.9(1.0)$ & $152.7(6.2)$ & $86.8(2.5)$ & $6.5(2.5)$ & $47.6(35.9-59.2)$ & $19.7(16.3-24.6)$ \\
\hline G4 & 50 & $12.9(0.8)$ & $160.5 \pm 6.8$ & $91.2(2.6)$ & $7.8(2.4)$ & $52.4(41.2-68.5)$ & $20.4(17.1-25.0)$ \\
\hline PHV & 130 & $13.2(1.0)$ & $162.4(7.3)$ & $91.5(2.8)$ & $11.0(2.2)$ & $54.5(42.2-69.8)$ & $20.4(17.4-25.5)$ \\
\hline PWV & 104 & $13.5(1.1)$ & & & & $59.5(45.3-79.6)$ & $26.0(22.2-31.2)$ \\
\hline $\begin{array}{l}\text { Final } \\
\text { height }\end{array}$ & 40 & 17.1 & $175.9(5.1)$ & & & 74.8 (61.8-91.6) & $24.3(20.6-29.4)$ \\
\hline
\end{tabular}

PP: Prepuberty, PHV: Peak height velocity, PWV: Peak weight velocity

$4.2(1.0)$ years.

\section{DISCUSSION}

Our data show that in the last decade of the twentieth century, middle to upper class Athenian schoolboys entered puberty at a mean age of 10.3 years. In a study carried out in Athens in 1968 in which testicular size and not genitalia Tanner staging classification was used, it was found that testicular enlargement began between the $10^{\text {th }}$ and $11^{\text {th }}$ year of age. ${ }^{8}$ In another study on the sexual maturation of Athenian boys carried out in 1978, a testicular volume of $4 \mathrm{ml}$ was reported to occur at a mean age of 10.8 years. ${ }^{9}$ It has recently been reported that in the 1990s the mean age at pubertal stage G2 of mainly middle class Athenian boys was 11.0 years. ${ }^{10}$ All the aforementioned studies were cross-sectional and the ages could be at least 0.5 year earlier. The lower age at onset to puberty observed in the present study may be due to its longitudinal nature and possibly to the higher socioeconomic class of the boys, or both, ${ }^{11,12}$ rather than to a secular trend.

The onset of puberty in our study is earlier than that reported in most other similar studies of Caucasian populations, both cross-sectional and longitudinal. ${ }^{4,5,13-17}$ However, the recent studies from the American NHANES III showed that in non-Hispanic white boys median age at $\mathrm{G} 2$ was 10.03 years, ${ }^{18}$ while in European studies (East Germany) G2 was at 10.8 years. ${ }^{19}$ The $\%$ of the final height achieved at the age of peak height velocity is higher than that indicated by
Greulich and Pyle data. ${ }^{20}$ No valid interpretation can be given for this difference but it could be attributed to genetic factors or a secular trend.

In the present study pubic hair developed significantly earlier than in other American and European populations. ${ }^{21,22}$ This could be due to genetic reasons or secular trend.

During development there is an increase in total body fat, as is shown by the increase in BMI, after the age of 6 years until maturity. ${ }^{23}$ However, during male puberty there is a decrease in percent body fat due to the increase of lean body mass as a result of the androgen effect. ${ }^{24,25}$ The BMI values in the different pubertal stages, at PHV and at final height are reported for the first time and, although they do not accurately reflect body fat mass, ${ }^{26}$ they demonstrate an interesting evolution of body mass related to the various facets of the pubertal process.

We present a longitudinal study on pubertal maturation of Greek boys. Since longitudinal data are somewhat sparse especially for males, the present data could be useful in delineating prognosis for puberty evolution and for final height in boys.

\section{REFERENCES}

1. Tanner JM 1989 Foetus into Man. Castlemead Publications, Ware.

2. Rees Hauspie RC, Vercauteren M, Susane C, 1997 Secular changes in growth and maturation; an update. Acta Paediatr Suppl 425: 20-27.

3. Largo RH, Prader A, 1983 Pubertal development in Swiss 
boys. Helv Paediatr Acta 38: 211-228.

4. Biro FM, Lucky AW, Huster GA, Morrison JA, 1995 Pubertal staging in boys. J Pediatr 127: 100-102.

5. Brook CGD 1982 Growth assessment in childhood and adolescence. Oxford: Blackwell Scientific Publications.

6. Cameron N 1986 The methods of auxological anthropometry. In: Falkner F, Tanner JM. Human growth. A comprehensive treatise. Vol 3, $2^{\text {nd }}$ ed. Plenum Press, New York, London.

7. Norusis M 1990 SPSS/PC+4.0 Base Manual. SPSS International BV, Netherlands.

8. Batrinos M 1974 Normal puberty of the male. In: Contemporary Endocrinology, Batrinos ML, ed, Parisianos, Athens; pp, 620-623.

9. Papadimitriou A, Chiotis D, Tsiftis G, et al, 2002 Secular growth changes in the Hellenic population in the twentieth century. Hormones 1: 245-250.

10. Papadimitriou A, Stephanou N, Papantzimas K, Glynos G, Philippidis P, 2002 Sexual maturation of Greek boys. Ann Hum Biol 29: 105-108.

11. Marshall WA, Tanner JM, 1970 Variations in the pattern of pubertal changes in boys. Arch Dis Child 45: 13-23.

12. Taranger J, Engstrom I, Lichtenstein H, SvennbergRedegren I, 1976 The somatic development of children in a Swedish urban community. VI. Somatic pubertal development. Acta Paediatrica Scand Suppl 258: 121135.

13. Buckler J, 1990 A longitudinal study of adolescent growth. London: Springer-Verlag.

14. Roche AF, Wellens R, Attie KM, Siervogel RM, 1995 The timing of sexual maturation in a group of US white youths. J Pediatr Endocrinol Metab 8: 11-18.

15. Mul D, Fredriks AM, van Buuren S, Oostdijk W, Verloove-Vanhorick SP, Wit JM, 2001 Pubertal development in the Netherlands 1965-1997. Pediatr Res 50: 479-486.

16. Sun SS, Schubert CM, Chumlea WC, et al, 2002 National estimates of the timing of sexual maturation and racial differences among US children. Pediatrics 110: 911919.

17. Buckler JMH 1998 Growth at adolescence. In: Kelnar CJH, Savage MO, Stirling HF, Saenger P, eds. Growth Disorders: Pathophysiology and Treatment. London: Chapman and Hall Medical, pp, 179-193.

18. Karpari AM, Rubin CH, Kieszak SM, Marcus M, Troiano RP, 2002 Stature and pubertal assessment in American boys: the 1988-1994 Third National Health and Nutrition Examination Survey. J Adolesc Health 30: 205-212.

19. Willers B, Engelhardt L, Pelz L, 1996 Sexual maturation in East German boys. Acta Paediatr 85: 785-788.

20. Greulich W, Pyle S 1959 Radiographic atlas of skeletal development of the hand and wrist. Stanford: Stanford University Press.

21. Herman-Giddens ME, Wang L, Koch G, 2001 Secondary sexual characteristics in boys: estimates from the national health and nutrition examination survey III, 1988-1994. Arch Pediatr Adolesc Med 155: 1022-1028

22. Preece MA, Heinrich I, 1981 Mathematical modeling of individual growth curves. Br Med Bull 37: 247-252.

23. Roche AF, Siervogel RM, Chumlea WB, Webb P, 1981 Grading body fatness from limited anthropometric data. Am J Clin Nutr 34: 2831-2838.

24. Rolland-Cachera MF, Cole TJ, Sempe M, 1991 Body mass index variations-centiles from birth to 87 years. Eur J Clin Nutr 45: 13-21.

25. Rolland-Cachera MF, 1993 Body composition during adolescence: methods, limitations, and determinants. Horm Res 39: Suppl: 25-50.

26. Wells JC, Coward WA, Cole TJ, Davies PS, 2002 The contribution of fat and fat-free tissue to body mass index in contemporary children and the reference child. Int $\mathbf{J}$ Obes Relat Metab Disord 26: 1323-1328. 